\title{
The Biochemical and Genetic Basis for High Frequency Thiomethyl Galactoside Resistance in $\lambda, \lambda d g$ Lysogens of Escherichia coli
}

\author{
By MARGARET E. RANEY \\ Department of Radiation Medicine, Roswell Park Memorial Institute. \\ Buffalo, New York 14263, U.S.A. \\ AND ROSEMARY W. ELLIOTT \\ Department of Molecular Biology, Roswell Park Memorial Institute
}

(Received 21 July 1977; revised 27 September 1977)

\begin{abstract}
In a culture of Escherichia coli $\mathrm{K} 12 \mathrm{gal}(\lambda d g)$, cells which form large colonies on agar plates containing galactose and thiomethyl $\beta$-D-galactoside (TMG) appear at high frequency. These clones are resistant to growth inhibition by TMG on galactose minimal medium. Biochemical studies of the steady-state levels of galactokinase and UDPgalactose 4-epimerase suggest that the resistant clones have extra copies of the genes for the galactosemetabolizing enzymes. The mutation for TMG resistance is not located in either the bacterial or the bacteriophage genome, but is probably due to an aberrant association between cell and prophage DNA.

Mapping the TMG-resistant characteristic by phage P1 indicates that TMG-resistant bacteria possess at least two $\mathrm{gal}^{+}$operons, one of which is cotransducible with $\mathrm{bio}^{+}$. In addition, TMG-resistant bacteria behave like $\lambda d g$ polylysogens when challenged with the phage $\lambda c 190 \mathrm{c17}$. From these genetic experiments we conclude that TMG-resistant bacteria arise by duplication of the $\lambda d g$ prophage. Finally, $g^{+} l^{+}$bacteria which carry a single, additional, $\lambda d g$ prophage are TMG-resistant. TMG resistance is probably a $\mathrm{gal}^{+}$gene dosage effect.
\end{abstract}

\section{INTRODUCTION}

When prototrophic $\mathrm{gal}^{+}$Escherichia coli bacteria are grown on minimal agar plates with galactose as the sole carbon source, they form high levels of the three enzymes coded for by the galactose operon (Buttin, 1963a) and produce large colonies. If a repressor of the galactose operon, thiomethyl $\beta$-D-galactoside (TMG) (Buttin, 1963a), is also present, the enzyme levels are low and very small colonies are formed. Wild-type cultures contain mutants, about 1 in $10^{7}$ bacteria, which are able to form large colonies on galactose-TMG plates. These mutants show an altered regulation of the galactose operon (Buttin, 1963b). They synthesize the galactose-metabolizing enzymes constitutively and their enzyme levels and the rate of growth of a culture metabolizing galactose are not affected by the presence of repressors of the galactose pathway such as TMG.

We have found that when cultures of $E$. coli transduced from $\mathrm{gal}$ to $\mathrm{gal}^{+}$with $\lambda d g$ [a defective $\lambda$ phage in which bacterial genes, including the galactose locus, have replaced certain bacteriophage genes (Morse, Lederberg \& Lederberg, 1956)] are plated on galactoseTMG plates, large colonies are formed at frequencies of up to $10 \%$ (Elliott, 1970). However, the majority of the colonies are very small. We shall designate the small colonies as TMG-sensitive (TMG ${ }^{\mathrm{s}}$ ) and the large colonies as TMG-resistant (TMG ${ }^{\mathrm{r}}$ ). 
This paper describes the biochemical properties of $\mathrm{TMG}^{\mathbf{r}}$ clones and the conditions under which the $\mathrm{TMG}^{\mathrm{r}}$ phenotype is expressed, and presents an analysis of the genetic basis for this high frequency mutation. The mutation to $\mathrm{TMG}^{\mathrm{r}}$ is not located in either the recipient bacterial genome or the phage genome, but could be due either to insertion of the prophage at an abnormal site or to duplication of the $\lambda d g$ prophage. Abnormal insertion of the prophage might interrupt the normal regulation of the galactose operon. Duplications of the $\lambda d g$ prophage would provide the cell with multiple copies of the galactose operon and in this case the $\mathrm{TMG}^{\mathrm{r}}$ phenotype might be the result of an increase in $\mathrm{gal}^{+}$ gene dosage.

The presence of gene duplications has been demonstrated in the genome of many organisms (Ohno, 1970), including E. coli (Russell et al., 1970). A variation of gene duplication was observed in $\lambda d g$ lysogens of $E$. coli gal deletion strains by Olsen \& Paigen (1972). In their study, duplication of the entire $\lambda d g$ prophage was demonstrated. Our results indicate that $\mathrm{TMG}^{\mathrm{r}}$ bacteria possess a $\lambda d g$ duplication. Furthermore the TMGr phenotype was expressed in bacteria of the genotype $\mathrm{gal}^{+}(\lambda d g)$, another combination of two functional galactose operons. Therefore TMG resistance appears to be a $\mathrm{gal}^{+}$gene dosage effect.

\section{METHODS}

Chemicals. TMG was purchased from Mann Research Laboratories, New York, U.S.A. and from Cyclo Chemical, Los Angeles, California, U.S.A.; D(+)-fucose from General Biochemicals Corp., Chagrin Falls, Ohio, U.S.A.; glucose-free galactose, NAD, ATP, UDPglucose and UDPglucose dehydrogenase from Sigma; dithiothreitol, chloramphenicol and UDPgalactose from Calbiochem; lysozyme from Worthington Biochemical Corp.; Casamino acids from Difco; and $\left[{ }^{14} \mathrm{C}\right]$ galactose from New England Nuclear.

Bacterial strains. The strain, source and genetic constitution of the E. coli $\mathrm{K} 12$ stock cultures are listed in Table 1.

Bacteriophage. The non-transducing lysate, $\lambda$ NFT, was obtained from strain $s 165(\lambda)$, and $\lambda$ HFT, a high frequency transducing lysate, from strain Q23. The phage $\lambda$ c190c17 was contributed by Dr K. Krell. Wildtype $\lambda^{+}, \lambda$ vir and P1 bacteriophages were obtained from Dr K. Paigen.

Media. Tryptone broth containing $1 \%(\mathrm{w} / \mathrm{v})$ Bacto-tryptone and $0.5 \%(\mathrm{w} / \mathrm{v}) \mathrm{NaCl}$ was adjusted to pH $7 \cdot 2 \pm 0 \cdot 2$. Tryptone broth was solidified with 0.65 or $1.5 \%(w / v)$ agar for top agar and agar plates, respectively. For experiments with $\mathrm{P} 1$, tryptone agar was supplemented with $0.5 \%(\mathrm{w} / \mathrm{v})$ yeast extract, $0.1 \%(\mathrm{w} / \mathrm{v})$ glucose, $0.003 \%(\mathrm{w} / \mathrm{v})$ thymine and $2.5 \mathrm{mM}-\mathrm{CaCl}_{2}$ (LB agar medium; Lennox, 1955). For EMB-galactose indicator plates, tryptone agar was supplemented with $0.1 \%$ yeast extract, $0.25 \%(\mathrm{w} / \mathrm{v})$ eosin powder and $1 \%(\mathrm{w} / \mathrm{v})$ galactose (added after autoclaving).

Minimal medium (M9; Anderson, 1946) and minimal agar contained $1.3 \% \mathrm{Na}_{2} \mathrm{HPO}_{4}, 0.1 \% \mathrm{KH}_{2} \mathrm{PO}_{4}$, $0.1 \% \mathrm{NH}_{4} \mathrm{Cl}, 0.001 \mathrm{M}-\mathrm{MgSO}_{4}, 0.05 \% \mathrm{NaCl}, 30 \mu \mathrm{M}-\mathrm{FeCl}_{3}$ (in $0.1 \mathrm{M}-\mathrm{HCl}$ ), $0.001 \%$ gelatin and $0.1 \%$ carbon source (all \% are \%, w/v). TMG was used at $10^{-2} \mathrm{M}$ when required. Amino acids were added to a final concentration of $20 \mu \mathrm{g} \mathrm{ml}^{-1}$ when required. Agar concentrations were the same as for broth media.

$\mathrm{K}$ medium was M9 medium with $0.1 \%$ glucose and $1.5 \%(\mathrm{w} / \mathrm{v})$ Casamino acids. The Casamino acids $(3 \%)$ were first treated with charcoal until the absorbance at $260 \mathrm{~nm}$ was less than $0 \cdot 1$.

Colony diameter measurements. M9 agar $(7 \mathrm{ml})$ with galactose $(0.1 \%)$ as carbon source, and either with or without TMG $\left(10^{-2} \mathrm{M}\right)$, was poured into $60 \mathrm{~mm}$ diam. plates. The plates were spread with bacteria previously grown by aeration in M9 galactose medium and diluted so that each plate contained 50 to 100 colonies. They were incubated at $37^{\circ} \mathrm{C}$ until colony growth stopped, but before overgrowth by mucoid mutants occurred. Colony diameters were measured using an American Optical microscope, with an eyepiece fitted with a micrometer disc, which was calibrated using a stage micrometer. At least 20 colonies of each strain were measured.

Bacterial growth. Cells were aerated at $37{ }^{\circ} \mathrm{C}$ in minimal medium containing glycerol. They were grown and prepared for assay as described by Williams \& Paigen (1969), with $0.1 \%$ glycerol as carbon source. The inducers fucose ( $5 \mathrm{mM})$ and galactose $(0.1 \%)$ and the repressor TMG $\left(10^{-2} \mathrm{M}\right)$ were added as indicated.

Enzyme assays. Galactokinase (ATP:D-galactose 1-phosphotransferase; EC 2:7.1.6) activity was assayed by a modification (Williams \& Paigen, 1969) of the original method of Sherman (1963). UDPgalactose 4-epimerase (UDPglucose 4-epimerase; EC 5.1.3.2) activity was assayed by the two-step method (Kalckar, Kurahashi \& Jordan, 1959).

For steady-state studies of galactokinase levels (Table 3), glycerol and galactose were present at $0.1 \%$, fucose at $5 \mathrm{mM}$ and TMG at $10^{-2} \mathrm{M}$. Activity is expressed as mol galactose 1-phosphate produced $A^{-1} \mathrm{~min}^{-1}$. 


\section{Table 1. Strains of Escherichia coli $\mathrm{K} 12$}

Strain
w3110
$21 \mathrm{a}, 51 \mathrm{a}$ and 71a
w3110 $(\lambda)$
w3350
$7 \mathrm{a}$ and 11a
$11 \mathrm{a} 3,13 \mathrm{~b} 2$ and $19 \mathrm{b3}$
w3350( $\lambda)$
w3805
w3805( $\lambda)$
Q22
Q22 $(\lambda)$
Q23
$1 \mathrm{~K}, 2 \mathrm{~A}$ and 2C
$2 \mathrm{E}, 2 \mathrm{H}$ and 2I
w602
w602/ $\lambda$
s165( $\lambda)$
C812
Q200D $\dagger$
N215
N1470
N1471

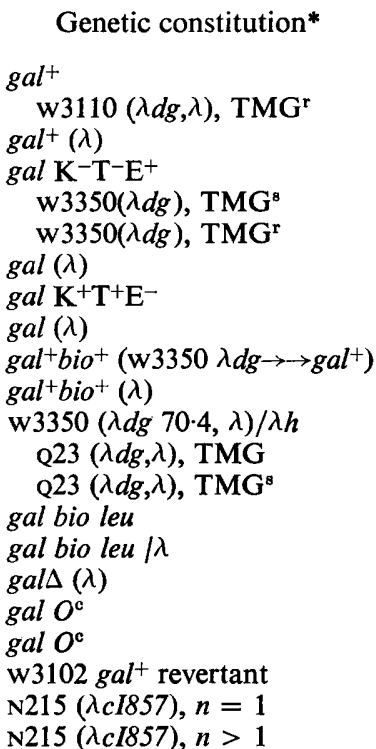

$\quad$ Source
J. Weigle
This study
K. Paigen
J. Weigle
This study
This study
K. Paigen
E. Lederberg
K. Paigen
K. Paigen
K. Paigen
K. Paigen
This study
This study
A. Campbell
This study
S. Adyha
G. Buttin
This study
K. Krell
K. Krell
K. Krell

* Abbreviations: K, galactokinase; T, galactose-1-phosphate uridylyltransferase; E, galactose 4-epimerase; $\Delta$, deletion.

$\dagger$ Derived by transudcing Buttin's $O^{\circ}$ mutant (c812), via $\lambda d g$, into w3350 and selecting a non-segregating transductant.

Cell mass was measured in absorbance units at $550 \mathrm{~nm}$ in a Gilford 240 spectrophotometer. An absorbance unit of 1.0 is equal to $6.5 \times 10^{8}$ viable bacteria $\mathrm{ml}^{-1}$ and 0.24 or $0.3 \mathrm{mg}$ protein $\mathrm{ml}^{-1}$, depending on the bacterial strain and growth conditions.

Preparation of bacteriophage lysates. All transducing or non-transducing lysates of $\lambda$ were prepared by ultraviolet (u.v.) induction of lysogens. Bacteria were grown overnight with aeration in K or M9 medium at $37^{\circ} \mathrm{C}$, then diluted in the same medium until the absorbance at $550 \mathrm{~nm}$ was about $0 \cdot 1$. The culture was irradiated in a thin layer using two General Electric $15 \mathrm{~W}$ germicidal bulbs at an approximate distance of $62 \mathrm{~cm}$ for 30 to $40 \mathrm{~s}$ (an approximate dose of 0.5 to $1 \mathrm{~J} \mathrm{~m}^{-2}$ ) and aerated in the dark until lysis occurred. A few drops of chloroform were added and aeration was continued for $5 \mathrm{~min}$. The lysate was centrifuged (Sorvall centrifuge SS-1, $\left.8500 \mathrm{rev} . \mathrm{min}^{-1}, 20 \mathrm{~min}\right)$, filtered through a Millipore membrane $(0.45 \mu \mathrm{m}$ pore size) and stored over chloroform.

P1 lysates were prepared on strains Q22, Q22( $\lambda$, w3110, $1 \mathrm{~K}$ and $2 \mathrm{H}$ by the method of Swanstrom \& Adams (1951), using LB agar medium.

Buoyant density centrifugation. Buoyant density in caesium chloride was determined by the method of Weigle, Meselson \& Paigen (1959).

Transduction with $\mathrm{P} 1$ : determination of $\mathrm{gal}^{+}$and $\mathrm{bio}^{+}$transduction frequencies. The recipient strain, $w 602 / \lambda$, was grown overnight in tryptone broth containing $3.5 \mathrm{mM} \mathrm{CaCl}_{2} . \mathrm{P} 1$ phage from the donor strains Q22, $\mathrm{Q} 22(\lambda), \mathrm{w} 3110,1 \mathrm{~K}$ or $2 \mathrm{H}$ were added to $\mathrm{w} 602 / \lambda$ cells at the desired input ratio. Controls containing bacteria alone and phage alone were included in each experiment. After $20 \mathrm{~min}$ the mixtures were plated on to the appropriate media for the selection of $\mathrm{Gal}^{+}, \mathrm{Bio}^{+}$or $\mathrm{Leu}^{+}$transductants or $\mathrm{Gal}^{+} \mathrm{Bio}^{+}$cotransductants. The input ratio was calculated from the recipient cell and phage titres and the transductant titre per $\mathrm{ml}$ adsorption mixture was determined.

Analysis of $\mathrm{gal}^{+}$and bio $^{+} \mathrm{P} 1$ transductants for distribution of unselected markers. gal ${ }^{+}$transductants and $b i o^{+}$transductants from the P1 transduction experiment were tested for the presence of the other markers by replica-plating on to appropriate selective minimal media plates by the method of Lederberg \& Lederberg (1952). Transductants to be tested for the biotin marker were replica-plated according to the technique of Rothman (1965), using an intermediate water agar replica-plate to eliminate carry-over of biotin. Transductants to be tested for the presence of $\lambda$ were replica-plated on to tryptone plates containing a $\lambda$-sensitive bacterial lawn (w3350) with and without exposure to u.v. light. A total of 200 to 400 colonies for each marker for each experiment were tested. 
Transduction with $\lambda, \lambda d g$ lysates. Overnight cultures of w3350 and w3110 were grown in defined glycerol medium at $37^{\circ} \mathrm{C}$. A $\lambda$ HFT lysate was obtained by u.v. induction of Q23. Phage and bacteria were mixed together to obtain the desired input ratio in a final volume of $1 \mathrm{ml}$ at a concentration of $1 \times 10^{8}$ to $1 \times 10^{8}$ bacteria $\mathrm{ml}^{-1}$. After $20 \mathrm{~min}$ at $37^{\circ} \mathrm{C}$ the mixture was plated by the spread method or as $0.01 \mathrm{ml}$ spots on M9 galactose or M9 galactose-TMG plates.

\section{RESULTS}

\section{Occurrence of $T M G^{\mathrm{r}}$ clones}

Colonies which appear to be $\mathrm{TMG}^{\mathrm{r}}$ have been found after plating established cultures each carrying an independently derived $\lambda d g$ in bacteria which are otherwise $\mathrm{Gal}^{-}$. These cultures included w3350 and w3805 lysogenized with lysates containing $\lambda d g$ nos 1,2 and 6 (Weigle et al., 1959), as well as $\lambda d g$ isolated from other bacterial strains including w3110 $(\lambda)$, w3805( $\lambda)$ and w3350 $(\lambda)$. All such cultures formed some large colonies on galactose-TMG plates. The presence of a $\lambda$ prophage is not necessary for the formation of $\mathrm{TMG}^{\mathrm{r}}$ clones, as cultures with the genetic constitution of $g a l(\lambda d g)$ form $\mathrm{TMG}^{\mathrm{r}}$ clones at the same frequency as cultures with the genetic constitution of $g a l(\lambda, \lambda d g)$.

$\mathrm{TMG}^{\mathrm{r}}$ colonies were also found among the new transductants formed when lysates containing $\lambda d g$ were adsorbed to $g a l$ bacteria and the resulting adsorption complexes were plated on galactose-TMG plates. Several different $\lambda d g$ lysates, including both highand low-frequency transducing lysates, were tested in this way. TMGr clones were found among the transductants from all lysates. In each case some clones maintained their TMGr phenotypes after subcloning six times.

\section{Colony diameters on galactose minimal medium}

Table 2 shows the mean and $95 \%$ confidence limits for the diameters of colonies on minimal galactose agar with and without TMG. On galactose agar, $\mathrm{Gal}^{+}$wild-type and transductant bacteria formed colonies of essentially the same size. In contrast, growth of the operator constitutive mutant $\left(O^{\mathrm{c}}\right)$ was inhibited by galactose on minimal medium as indicated by its smaller colony size. This inhibition was characteristic of this $O^{\mathrm{c}}$ mutant after transduction into w3350. In the presence of TMG, growth of wild-type $\mathrm{Gal}^{+}$colonies was severely inhibited, as was growth of the $\mathrm{TMG}^{\mathrm{s}}$ transductant. The operator constitutive and the $\mathrm{TMG}^{\mathrm{r}}$ transductant formed much larger colonies, almost twice the diameter of colonies from the $\mathrm{Gal}^{+}$bacteria and $\mathrm{TMG}^{\mathrm{s}}$ transductant.

\section{Formation of $T M G^{\mathbf{r}}$ clones}

The frequency of appearance of large colonies from an uncloned culture of Q23 was $1.5 \%$. Strain Q23 was streaked on a series of minimal plates with glycerol or glucose as the carbon source. Individual colonies were picked from the non-selective minimal plates, resuspended in dilution medium and plated on minimal galactose plates either with or without TMG. Of the 60 clones studied, 2 were $\mathrm{Gal}^{-}, 2$ were $100 \% \mathrm{TMG}^{\mathrm{r}}, 8$ were $100 \%$ $\mathrm{TMG}^{\mathrm{s}}$, and the remaining 48 contained from 0 to $50 \% \mathrm{TMG}^{\mathrm{r}}$ colonies. The frequency of $\mathrm{Gal}^{-}$colonies, about $4 \%$, was not unexpected in an uncloned culture.

Previous exposure to TMG is not required for the formation of $\mathrm{TMG}^{\mathbf{r}}$ clones, since two such clones which had not been previously exposed were obtained. On further study, these clones segregated $\mathrm{TMG}^{\mathrm{s}}$ colonies at low frequency, but have remained stable since they were selected. None of the colonies which were selected as being large on TMG were homogeneous in this respect, but all contained some bacteria which were capable of forming large colonies.

$\mathrm{Gal}^{+}$clones which are incapable of forming $\mathrm{TMG}^{\mathrm{r}}$ colonies no longer contain the $\lambda d g$ prophage. They have presumably become $\mathrm{gal}^{+}$due to a recombinational event within the bacterial galactose gene, rather than by integration of $\lambda d g$. So far we have found no completely stable $\mathrm{TMG}^{\mathrm{r}}$ clones analogous to the stable $\mathrm{TMG}^{\mathrm{s}}$ phenotype. Presumably these would be represented by constitutive mutants for the galactose operon, which occur 
Table 2. Colony diameters on minimal galactose agar with and without TMG

Results are expressed as the mean of at least 20 measurements $\pm 95 \%$ confidence limits of the mean.

\begin{tabular}{lccc} 
& & \multicolumn{2}{c}{ Colony diameter (mm) } \\
Strain & Phenotype & Without TMG & With TMG \\
w3110 & Gal $^{+}$ & $0.414 \pm 0.036$ & $0 \cdot 180 \pm 0.026$ \\
Q200D & Gal O$^{\text {c }}$ & $0.219 \pm 0.020$ & $0.573 \pm 0.026$ \\
2H & TMG $^{\mathrm{B}}$ & $0.432 \pm 0.024$ & $0 \cdot 287 \pm 0.037$ \\
1K & TMG $^{\mathbf{r}}$ & $0.468 \pm 0.038$ & $0.504 \pm 0.048$
\end{tabular}

Table 3. Steady-state levels of galactokinase in the presence or absence of inducers and repressors

Activities are expressed as mol galactose 1-phosphate produced $A^{-1} \mathrm{~min}^{-1}$.

Addition(s) to minimal salts medium

\begin{tabular}{|c|c|c|c|c|c|c|c|c|}
\hline Strain & $\begin{array}{l}\text { Glycerol } \\
\text { (1) }\end{array}$ & $\begin{array}{l}\text { Glycerol } \\
\text { Fucose } \\
\text { (2) }\end{array}$ & $\begin{array}{c}\text { Glycerol } \\
\text { TMG } \\
\text { (3) }\end{array}$ & $\begin{array}{c}\text { Glycerol } \\
\text { Fucose } \\
\text { TMG } \\
\text { (4) }\end{array}$ & $\begin{array}{c}\text { Galactose } \\
\text { (5) }\end{array}$ & $\begin{array}{c}\text { Galactose } \\
\text { Glycerol } \\
\text { (6) }\end{array}$ & $\begin{array}{c}\text { Galactose } \\
\text { TMG } \\
\text { (7) }\end{array}$ & $\begin{array}{c}\text { Galactose } \\
\text { Glycerol } \\
\text { TMG } \\
\text { (8) }\end{array}$ \\
\hline w3110 & $0 \cdot 114$ & 1.84 & $0 \cdot 148$ & 0.212 & 0.858 & 1.050 & 1.020 & 0.460 \\
\hline $\begin{array}{l}2 \mathrm{E} \\
2 \mathrm{H} \\
2 \mathrm{I}\end{array}$ & $\begin{array}{l}0.062 \\
0.080 \\
0.064\end{array}$ & $\begin{array}{l}1 \cdot 12 \\
1.43 \\
1.05\end{array}$ & $\begin{array}{l}0 \cdot 110 \\
0 \cdot 121 \\
0 \cdot 087\end{array}$ & $\begin{array}{l}0 \cdot 149 \\
0 \cdot 163 \\
0 \cdot 166\end{array}$ & $\begin{array}{l}1 \cdot 260 \\
1 \cdot 120 \\
1 \cdot 100\end{array}$ & $\begin{array}{l}0.814 \\
0.725 \\
0.700\end{array}$ & $\begin{array}{l}0.919 \\
0.648 \\
0.727\end{array}$ & $\begin{array}{l}0.356 \\
0.446 \\
0.372\end{array}$ \\
\hline $\begin{array}{l}1 \mathrm{~K} \\
2 \mathrm{~A} \\
2 \mathrm{C}\end{array}$ & $\begin{array}{l}0.370 \\
0 \cdot 193 \\
0 \cdot 209\end{array}$ & $\begin{array}{l}3 \cdot 56 \\
2 \cdot 08 \\
3 \cdot 52\end{array}$ & $\begin{array}{l}0.426 \\
0.229 \\
0.342\end{array}$ & $\begin{array}{l}0.473 \\
0.223 \\
0.509\end{array}$ & $\begin{array}{l}2 \cdot 180 \\
1 \cdot 270 \\
1 \cdot 940\end{array}$ & $\begin{array}{l}1.570 \\
0.982 \\
0.742\end{array}$ & $\begin{array}{l}1.830 \\
1.210 \\
1.980\end{array}$ & $\begin{array}{l}0.880 \\
0.566 \\
1.050\end{array}$ \\
\hline Q200D & 2.050 & 4.00 & 1.410 & 1.439 & 5.970 & $2 \cdot 890$ & $2 \cdot 440$ & 1.940 \\
\hline
\end{tabular}

at a very low frequency. In all subsequent work, we have been careful to check that the culture contained a majority of bacteria of one phenotype and a minority (no more than $10 \%$ ) of the other.

A series of growth studies in liquid culture showed that the frequency of the minority type did not increase significantly over a $24 \mathrm{~h}$ growth period. However, in refrigerated stock cultures the frequency of the minority type did increase over a period of 7 to 30 days.

\section{Biochemical studies}

The following studies were done on three TMGr clones, $(1 \mathrm{~K}, 2 \mathrm{~A}$ and $2 \mathrm{C}$ ) and on three $\mathrm{TMG}^{\mathrm{B}}$ clones isolated at the same time (2E, $2 \mathrm{H}$ and $\left.2 \mathrm{I}\right)$. Steady-state levels of galactokinase in the presence or absence of inducers and repressors are shown in Table 3. The basal level of galactokinase (column 1) for all $\mathrm{TMG}^{\mathrm{s}}$ clones ranged from that of the control strain w3110 to about half this level, while for the TMGr strains, the basal level was from two to three times that of $\mathrm{w} 3110$. In no $\mathrm{TMG}^{\mathbf{r}}$ strain did the galactokinase level reach that of the constitutive strain Q200D. Similarly, the induced levels (column 2) in the TMGs clones were close to, but less than that of induced $w 3110$, while for the TMGr clones the induced enzyme levels were one to two times that of induced w3110 and close to that of the constitutive strain. The effect of the repressor TMG (column 3) on the basal level of all transductants was negligible, but this repressor essentially eliminated all of the inducing effect of fucose (column 4). All of the strains were induced by the non-gratuitous substrate galactose, whether or not it was added in the presence of another carbon source, glycerol (columns 5 and 6). The addition of TMG with galactose (column 7) did not prevent induction by galactose. The enzyme levels in the $\mathrm{TMG}^{\mathrm{s}}$ clones were decreased 
somewhat in the presence of TMG when galactose was the sole carbon source, but they remained greater than 10 times the basal level. When glycerol and galactose were both present with TMG (column 8), enzyme levels were decreased in all strains. However, none of these effects was sufficient to explain the behaviour of the clones on plates.

Under the same range of cultural conditions, the response of UDPgalactose 4-epimerase (results not shown) to the various effectors was comparable to that of the kinase. The main difference was that the $\mathrm{TMG}^{\mathrm{s}}$ cultures showed activities consistent with the presence in the bacterium of two copies of the epimerase gene, one in the cell genome and one in $\lambda d g$.

The $\mathrm{TMG}^{\mathrm{r}}$ clones thus appear to have an elevated basal level for the galactose-metabolizing enzymes and are inducible as wild type. Induction by the gratuitous inducer fucose is sensitive to repression by TMG to the respective basal level, while induction by the non-gratitutous inducer galactose is not sensitive at the concentrations we have tried.

\section{Where is the mutation?}

We have attempted to determine whether the alteration which causes the difference between $\mathrm{TMG}^{\mathrm{s}}$ and $\mathrm{TMG}^{\mathrm{r}}$ clones resides in the defective prophage, $\lambda d g$, or the bacterium. Cultures from $\mathrm{TMG}^{\mathrm{r}}$ clones and $\mathrm{TMG}^{\mathrm{s}}$ clones were induced with u.v. light to produce high frequency transducing lysates of $\lambda$ and $\lambda d g$. Bacteria from each clone were also spread on rich indicator plates and three independent $\mathrm{Gal}^{-}$segregants were obtained from three different sectored colonies from each clone. These $\mathrm{Gal}^{-}$segregants were grown and retransduced to $\mathrm{Gal}^{+}$by $\lambda d g$ lysates from clones both sensitive and resistant to TMG. All transductants produced both large and small colonies on plates containing TMG at approximately equal frequencies. It thus appears that the difference between $\mathrm{TMG}^{\mathrm{s}}$ and $\mathrm{TMG}^{\mathbf{r}}$ clones is not due to a mutation in either the prophage or the bacterium, but to a difference in the association between the two. To help confirm this, the buoyant density of both $\lambda$ and $\lambda d g$ produced by induction of $\mathrm{TMG}^{\mathrm{s}}$ and $\mathrm{TMG}^{\mathrm{r}}$ clones was determined and no significant difference between the phage populations was observed.

\section{$\mathrm{gal}^{+}$and bio ${ }^{+}$transduction with $\mathrm{P1}$}

To determine the position of the $\lambda d g$ prophage in $\mathrm{TMG}^{\mathrm{s}}$ and $\mathrm{TMG}^{\mathrm{r}}$ cells relative to $\lambda$ and bio, the frequencies of $\mathrm{gal}^{+}$and $\mathrm{bio}^{+}$transductants and cotransductants obtained from P1 lysates made on $\mathrm{TMG}^{\mathrm{s}}$ and $\mathrm{TMG}^{\mathrm{r}}$ clones were determined. For comparison, the transduction frequencies of these markers from a $\mathrm{gal}^{+} \mathrm{bio}^{+}(\lambda)$ lysogen and from its nonlysogenic parent were also observed. The values were normalized by expressing the transduction frequencies as the percentage of $l e u^{+}$transductants (Table 4). The observations were compared in two independent mapping experiments, one at a high and the other at a low P1 input ratio. The values for the non-lysogenic donor were comparable to those obtained by Rothman (1965). When the donor strain was a $\lambda$ lysogen, the frequency of both $\mathrm{gal}^{+}$and $\mathrm{bio}^{+}$transduction and particularly of $\mathrm{gal}^{+} \mathrm{bio}^{+}$cotransduction was decreased, as described by Rothman (1965).

In experiments with similar input ratios, $\mathrm{TMG}^{\mathrm{s}}$ and $\mathrm{TMG}^{\mathrm{r}}$ donors contributed $\mathrm{bio}^{+}$ transductants equally well. However, the $\mathbf{T M G}^{\mathbf{r}}$ donor contributed two to four times as many $\mathrm{gal}^{+}$transductants as the $\mathrm{TMG}^{\mathrm{s}}$ donor, suggesting that more than one $\mathrm{gal}^{+}$region was present in the $\mathrm{TMG}^{\mathbf{r}}$ donor. Furthermore, the frequency of $\mathrm{gal}^{+} \mathrm{bio}^{+}$cotransduction from $\mathrm{TMG}^{\mathrm{r}}$ bacteria was similar to that from $\mathrm{TMG}^{\mathrm{s}}$ bacteria and from $\mathrm{gal}^{+} \mathrm{bio}^{+} \lambda$ lysogens, suggesting that one $\mathrm{gal}^{+}$region in the $\mathrm{TMG}^{\mathbf{r}}$ cells has a normal position with respect to $\lambda$ and bio.

\section{Analysis of $\mathrm{gal}^{+}$and bio ${ }^{+} \mathrm{P} 1$ transductants for distribution of unselected markers}

$\mathrm{gal}^{+}$and $\mathrm{bio}^{+}$transductants were analysed for the distribution of unselected markers (Table 5). Almost all $\mathrm{gal}^{+} \mathrm{bio}^{+}$cotransductants were also lysogenic for $\lambda$. This latter observation is consistent with $\lambda$ being the middle marker between $\mathrm{gal}^{+}$and $\mathrm{bio}^{+}$(see Fig. 1). 


\section{Table 4. The frequency of $\mathrm{gal}^{+}$and bio $^{+}$transduction and cotransduction by phage $\mathrm{P} 1$}

The frequencies of $\mathrm{bio}^{+}$and $\mathrm{gal}^{+}$transductants and cotransductants are expressed as (the average number of colonies divided by the average number of $l e u^{+}$transductants) $\times 100 ; 95 \%$ confidence limits are also given. The numbers of each type of plate used are indicated in parentheses. The recipient strain was $w 602 / \lambda$.

\begin{tabular}{|c|c|c|c|c|c|c|}
\hline \multirow[b]{2}{*}{ Expt* } & \multirow[b]{2}{*}{ Donor } & \multirow{2}{*}{$\begin{array}{c}\text { Donor } \\
\text { genotype }\end{array}$} & \multirow{2}{*}{$\begin{array}{l}\text { Input } \\
\text { ratio }\end{array}$} & \multicolumn{3}{|c|}{ Percentage of $\mathrm{leu}^{+}$transductants } \\
\hline & & & & bio $^{+}$ & $\mathrm{gal}^{+}$ & $\mathrm{gal}^{+} \mathrm{bio}^{+}$ \\
\hline 1 & Q22 & $\begin{array}{l}\mathrm{gal}^{+} \mathrm{bio}^{+} \\
\mathrm{gal}^{+} \mathrm{hio}^{+}\end{array}$ & $\begin{array}{r}27.9 \\
4.9\end{array}$ & $\begin{array}{l}30 \cdot 1 \pm 17 \cdot 2(2) \\
18 \cdot 7+1.6(12)\end{array}$ & $\begin{array}{l}20 \cdot 1 \pm 3 \cdot 0(2) \\
18 \cdot 9+2 \cdot 3(10)\end{array}$ & $\begin{array}{r}11 \cdot 3 \pm 4 \cdot 8(3) \\
7.7+3.6\end{array}$ \\
\hline $\begin{array}{l}1 \\
2\end{array}$ & $\begin{array}{l}\text { Q22( }(\lambda) \\
\text { Q22( }(\lambda)\end{array}$ & $\begin{array}{l}\text { gal }^{+} \text {bio }^{+}(\lambda) \\
\text { gal }^{+} \text {bio }^{+}(\lambda)\end{array}$ & $\begin{array}{r}49 \cdot 5 \\
7 \cdot 0\end{array}$ & $\begin{array}{l}9 \cdot 6 \pm 4 \cdot 2(3) \\
2 \cdot 1 \pm 0 \cdot 30(11)\end{array}$ & $\begin{array}{l}10 \cdot 4 \pm 2 \cdot 5(4) \\
1 \cdot 6 \pm 0.81(12)\end{array}$ & $\begin{array}{r}1.3 \pm 0.76(3) \\
0.33 \pm 0.80(4)\end{array}$ \\
\hline $\begin{array}{l}1 \\
2\end{array}$ & $\begin{array}{l}2 \mathbf{H} \\
2 \mathbf{H}\end{array}$ & $\begin{array}{l}\mathrm{TMG}^{\mathrm{g}}(\lambda d g, \lambda) \\
\mathrm{TMG}^{\mathrm{s}}(\lambda d g, \lambda)\end{array}$ & $\begin{array}{r}18 \cdot 8 \\
2 \cdot 7\end{array}$ & $\begin{array}{l}6.5 \pm 1.9(7) \\
5.4 \pm 0.06(13)\end{array}$ & $\begin{array}{l}4 \cdot 3 \pm 0.14(6) \\
5 \cdot 4 \pm 0.93(13)\end{array}$ & $\begin{array}{r}0.44 \pm 0.39(6) \\
1.3 \pm 0.93(4)\end{array}$ \\
\hline $\begin{array}{l}1 \\
2\end{array}$ & $\begin{array}{l}1 \mathrm{~K} \\
1 \mathrm{~K}\end{array}$ & $\begin{array}{l}\operatorname{TMG}^{\mathbf{r}}(\lambda d g, \lambda) \\
\operatorname{TMG}^{\mathrm{r}}(\lambda d g, \lambda)\end{array}$ & $\begin{array}{r}17 \cdot 1 \\
3 \cdot 1\end{array}$ & $\begin{array}{l}6 \cdot 2 \pm 1.2(9) \\
7.0 \pm 1.6(13)\end{array}$ & $\begin{array}{l}15 \cdot 1 \pm 2 \cdot 6(8) \\
11 \cdot 4 \pm 1 \cdot 6(13)\end{array}$ & $\begin{array}{l}1.0 \pm 0.50(9) \\
1.8 \pm 0.54(4)\end{array}$ \\
\hline
\end{tabular}

* Experiments 1 and 2 represent two independent experiments run under the same conditions but at different $\mathrm{P1}$ input ratios. Table 5. Analysis of $\mathrm{gal}^{+}$and bio ${ }^{+} \mathrm{P} 1$ transductants for
distribution of unselected markers

A total of 200 to 400 colonies for each marker for each experiment was tested. The frequencies of cotransduction of unselected markers are expressed as (the number of colonies positive for the marker divided by the total number of colonies tested) $\times 100$.

\begin{tabular}{|c|c|c|c|c|c|c|c|}
\hline \multirow[b]{2}{*}{ Expt } & \multirow[b]{2}{*}{ Donor } & \multirow{2}{*}{$\begin{array}{c}\text { Donor } \\
\text { phenotype }\end{array}$} & \multirow{2}{*}{$\begin{array}{c}\text { Input } \\
\text { ratio }\end{array}$} & \multicolumn{2}{|c|}{$\begin{array}{l}\text { Cotransduction of } \\
\text { unselected markers in } \\
\text { bio }^{+} \text {transductants }\end{array}$} & \multicolumn{2}{|c|}{$\begin{array}{l}\text { Cotransduction of } \\
\text { unselected markers in } \\
\text { gal }^{+} \text {transductants }\end{array}$} \\
\hline & & & & $\operatorname{gal}(\lambda)$ & $\mathrm{gal}^{+*}$ & bio $(\lambda)$ & $\mathrm{bio}^{+*}$ \\
\hline 1 & $2 \mathrm{H}$ & $\mathrm{TMG}^{\mathrm{B}}$ & $18 \cdot 8$ & $33 \cdot 2$ & $9 \cdot 5$ & $24 \cdot 6$ & $24 \cdot 6$ \\
\hline 1 & $1 \mathrm{~K}$ & $\mathrm{TMG}^{\mathbf{r}}$ & $17 \cdot 1$ & $31 \cdot 2$ & 9.6 & $6 \cdot 5$ & $3 \cdot 2$ \\
\hline 2 & $2 \mathrm{H}$ & $\mathrm{TMG}^{\mathrm{s}}$ & $2 \cdot 7$ & $40 \cdot 2$ & $36 \cdot 7$ & $40 \cdot 7$ & $26 \cdot 3$ \\
\hline 2 & $1 \mathrm{~K}$ & $\mathrm{TMG}^{\mathbf{r}}$ & $3 \cdot 1$ & $48 \cdot 2$ & $36 \cdot 3$ & 25.9 & $13 \cdot 2$ \\
\hline
\end{tabular}

* Almost all $\mathrm{gal}^{+} \mathrm{bio}^{+}$cotransductants were also lysogenic for $\lambda$.

TMG-sensitive cell

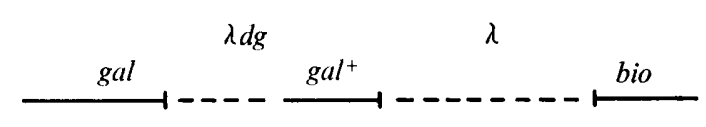

TMG-resistant cell

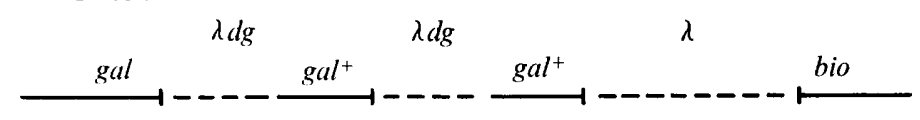

Fig. 1. Genotypes of TMG-sensitive and TMG-resistant cells.

Among the $\mathrm{bio}^{+}$transductants, the frequency of $\mathrm{gal}^{+}$clones was the same for both $\mathrm{TMG}^{\mathrm{s}}$ and $\mathrm{TMG}^{\mathrm{r}}$ donors. This result would be expected if one $\mathrm{gal}^{+}$region of the TMGr bacteria is in a normal position with respect to $\lambda$ and $b_{i o}{ }^{+}$.

When $\mathrm{gal}^{+}$was the selected marker and $\mathrm{TMG}^{\mathbf{r}}$ cells were the donors, the frequency of the unselected markers bio $^{+}$and $\lambda$ was significantly lower than when $\mathrm{TMG}^{\mathrm{s}}$ cells were 
donors. This result indicates that $\mathrm{TMG}^{\mathbf{r}}$ cells possessed one or more additional $\mathrm{gal}^{+}$ regions further away and not cotransducible with the $b^{+}{ }^{+}$locus. The position of a second $\mathrm{gal}^{+}$is most probably to the $\mathrm{gal}$ side of $\lambda$ as indicated in Fig. 1. However, we cannot completely rule out its presence at another site, although the data is not consistent with a location at the other end of $\lambda$, near $b^{+} o^{+}$.

\section{Test for cI gene dosage with $\lambda$ c190c17}

Additional $\mathrm{gal}^{+}$regions in $\mathrm{TMG}^{\mathbf{r}}$ bacteria could be a result of duplications of the $\mathrm{gal}^{+}$ region alone, or of duplications of the entire $\lambda d g$ prophage. It seemed likely that the multiple $\mathrm{gal}^{+}$regions in $\mathrm{TMG}^{\mathrm{r}}$ bacteria were a result of polylysogeny by $\lambda d g$ since both $\mathrm{TMG}^{\mathbf{r}}$ and $\mathrm{TMG}^{\mathrm{s}}$ clones were able to segregate gal colonies. To test this hypothesis, we used phage $\lambda c 190 c 17$ to test for polylysogeny. The mutation $c 17$ renders $\lambda$ insensitive to replication inhibition but the phage remains sensitive to repression for other phage functions. In an immune host, $\lambda c 17$ may replicate many times, but no mature phage are formed. If the mutation $\mathrm{cI90}$ is also present $(\lambda \mathrm{cl} 90 \mathrm{c17})$, the only functioning repressor would be that from the immunity region of the resident prophage. The virulent phenotype of phage $\lambda \mathrm{cI} 190 \mathrm{cl} 7 \mathrm{observed} \mathrm{in} \mathrm{such} \mathrm{a} \mathrm{situation} \mathrm{is} \mathrm{explained} \mathrm{in} \mathrm{that} \mathrm{multiple} \mathrm{copies} \mathrm{of}$ $\lambda c 190 c 17$ would exceed the number that can be repressed by a single resident prophage. If, however, the immune host possesses a high level of repressor, such as might be produced by a polylysogen, then the repressor capacity is not exceeded and $\lambda c 190 \mathrm{c} 17$ produces no plaques. Thus, the phage can be used to distinguish between single lysogens and polylysogens (Packman \& Sly, 1968; Sly \& Rabideau, 1969).

$\mathrm{TMG}^{\mathrm{s}}$ and $\mathrm{TMG}^{\mathrm{r}}$ cells containing $\lambda d g$ prophage, but no $\lambda$ prophage, were constructed. The polylysogeny test (Fig. 2) was then a test for the presence or absence of multiple $\lambda d g$ prophage. Control experiments (data not included) showed that $\lambda$ vir but not $\lambda^{+}$ formed plaques on both $\mathrm{TMG}^{\mathrm{s}}$ and $\mathrm{TMG}^{\mathrm{r}}$ bacteria, confirming that these clones were immune to $\lambda$ but not resistant to $\lambda$. Plaque formation of $\lambda c 190 c 17$ on TMGs lysogens was as efficient as on the known single lysogen. Plaques were not formed, however, on $\mathrm{TMG}^{\mathbf{r}}$ bacteria. Thus, TMGr clones behaved like $\lambda d g$ polylysogens.

\section{Test for gal gene dosage effect}

We have shown that TMGr bacteria result from duplications of the $\lambda d g$ prophage. The question now arises as to whether bacteria carrying one host $\mathrm{gal}^{+}$operon and one $\lambda d \mathrm{gal}^{+}$ prophage are $\mathrm{TMG}^{\mathrm{r}}$, or whether the two $\mathrm{gal}^{+}$operons must be in the prophage state for TMG resistance to be expressed. To test this, $g a l^{+}(\lambda d g, \lambda)$ clones were constructed by infecting $\mathrm{gal}^{+}$bacteria with $\lambda d g, \lambda$ lysates. The frequency of transduction of $\mathrm{gal}^{+}$bacteria to TMG resistance was compared with the frequency of transduction of gal bacteria to $\mathrm{gal}^{+}$(Table 6). The two frequencies were approximately the same, suggesting that every $\mathrm{gal}^{+}$cell receiving a $\lambda d g$ prophage became TMG-resistant.

The TMG-resistant colonies $\left(21 \mathrm{a}, 51 \mathrm{a}\right.$ and 71a) formed by transduction of the $\mathrm{gal}^{+}$ recipient cells retained the TMG-resistant characteristic through three clonings. As expected, the resistant clones did not segregate $\mathrm{Gal}^{-}$cells. Furthermore, the clones were much more stable on galactose-TMG plates than $\mathrm{gal}^{+}$polylysogens, segregating fewer small colonies. This is in accord with the greater stability of a single $\lambda d g$ lysogen compared with a polylysogen. Ultraviolet induction of the TMG-resistant clones derived from $\mathrm{gal}^{+}$bacteria produced HFT lysates, confirming that every clone tested was, in fact, lysogenic for both $\lambda d g$ and $\lambda$.

\section{DISCUSSION}

The ability to form large colonies on minimal galactose agar in the presence of the repressor TMG has so far been associated with regulatory mutants of the galactose pathway, $R^{-}$gal and $g a l O^{c}$ (Buttin, 1963b). In clones containing $\lambda d g$, the phenotype is 
Phage dilution

$10^{0} \quad 10^{-1 \cdot 5} \quad 10^{-3 \cdot 0} \quad 10^{-4 \cdot 5}$

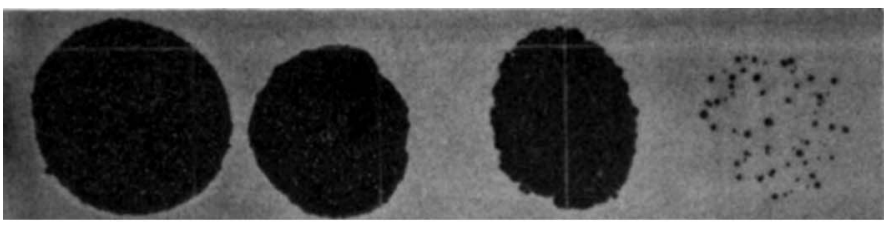

N215 Non-lysogen

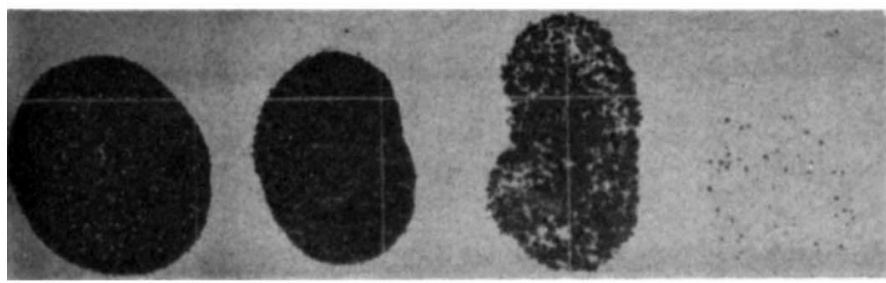

N1470( $\lambda$ cI857) Single lysogen

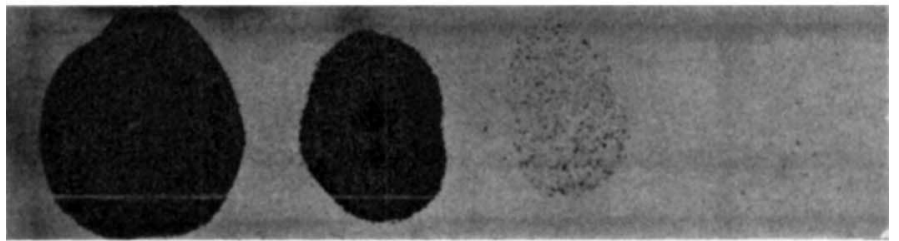

w $3350(\lambda d g)$ TMG-sensitive

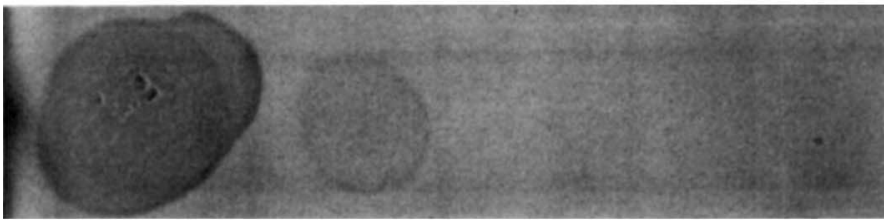

w3350 $(\lambda d g)$ TMG-resistant

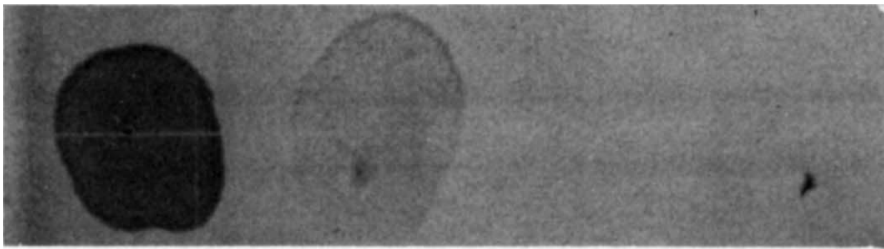

N1471( $\lambda c$ I857) Polylysogen

Fig. 2. Test of TMG-resistant clones for $\lambda d g$ polylysogeny. Each spot represents a different phage dilution. The bacterial seed is indicated beside each photograph.

Table 6. The frequency of transduction of gal + bacteria to $\mathrm{TMG}^{\mathrm{r}}$ compared with the frequency of transduction of gal bacteria to $\mathrm{Gal}^{+}$using $\lambda, \lambda d g$ phage lysates

No. of

transductants

$\begin{array}{cccccc}\begin{array}{c}\text { Recipient } \\ \text { strain }\end{array} & \begin{array}{c}\text { Recipient } \\ \text { genotype }\end{array} & \begin{array}{c}\lambda \\ \text { helper }\end{array} & \begin{array}{c}\lambda \text { input } \\ \text { ratio }\end{array} & \begin{array}{c}\text { Transductant } \\ \text { phenotype }\end{array} & \begin{array}{c}\text { transductants } \\ \text { per ml adsorption } \\ \text { mixture }\end{array} \\ \text { w3350 } & \text { gal } & - & 0.06 & \text { Gal }^{+} & 2.0 \times 10^{7} \\ \text { w3350 } & \text { gal } & + & 0 \cdot 14 & \text { Gal }^{+} & 2 \cdot 3 \times 10^{7} \\ \text { W3110 } & \text { gal }^{+} & - & 0 \cdot 14 & \text { TMG }^{\mathbf{r}} & 6.0 \times 10^{6} \\ \text { w3110 } & \text { gal }^{+} & + & 0.35 & \text { TMG }^{\mathbf{r}} & 6.0 \times 10^{6}\end{array}$


very frequent (of the order of $1 \%$ ) and these clones, unlike the regulatory mutants, are sensitive to regulation by fucose and TMG.

The ability to form $\mathrm{TMG}^{\mathrm{r}}$ colonies appears to be associated with the presence of $\lambda d g$ prophage. The presence of $\lambda$ prophage is irrelevant. A number of independently derived $\lambda d g$, when present as prophage, allowed the formation of $\mathrm{TMG}^{\mathrm{r}}$ clones, and a number of $g a l$ cells, after infection with $\lambda d g$, were also capable of forming such clones.

Neither the $\lambda d g$ nor the bacterium is permanently altered genetically by its participation in a $\mathrm{TMG}^{\mathrm{r}}$ clone. Thus it appears that the genetic basis for TMG resistance is due to an alteration in the association between the DNAs, either in the site of integration or in the number of defective prophages in the cell. The biochemical data is consistent with a gene dosage effect, but does not exclude the possibility that the prophage may have inserted in a secondary site at which the regulation of the galactose genes is aberrant.

The results from the genetic experiments indicate that the basis for TMG resistance is a duplication of the entire $\lambda d g$ prophage. These results are consistent with the findings of Olsen \& Paigen (1972). The presence of two or more gal $^{+}$regions in TMGr strains is indicated by the mapping experiment. The observation that $\mathrm{TMG}^{\mathbf{r}}$ cells segregate gal cells indicates that both of these regions are in the prophage state. That the two $\mathrm{gal}^{+}$regions are in separate prophages is indicated by the segregation of $\mathrm{gal}^{+} \mathrm{TMG}^{\mathbf{3}}$ bacteria. The polylysogenicity of TMGr bacteria was confirmed by the plating efficiency of $\lambda c 190 \mathrm{c} 17$.

By constructing $\mathrm{gal}^{+}(\lambda d g, \lambda)$ strains and testing them for TMG resistance, we were able to determine that one complete $\lambda d g$ in addition to another functional $\mathrm{gal}^{+}$region is sufficient to produce TMG resistance. This indicates that it is not multiple copies of the entire $\lambda d g$ prophage that are required for TMG resistance, but rather the presence of multiple $\mathrm{gal}^{+}$regions. It is likely, therefore, that TMG resistance is a $\mathrm{gal}^{+}$gene dosage effect. The hypothesis of a $\mathrm{gal}^{+}$gene dosage effect would be confirmed if a bacterium with two or more integrated $\mathrm{gal}^{+}$regions with no prophage proved to be TMGr.

Prophage duplications raise questions as to the mechanism of duplication. Brooks (1965) suggested that $\lambda d g$ may replicate several times before integration and subsequent multiple integrations can take place. In our system, formation of TMG ${ }^{\mathbf{r}}$ bacteria by $\lambda d g$ duplication takes place readily in bacteria in which single $\lambda d g$ lysogenicity is already established (TMG ${ }^{\mathrm{s}}$ bacteria). In this case, the $\lambda d g$ may excise and replicate, and then multiple copies reintegrate in tandem, since the BP' $^{\prime}$ region for integration is provided (Guerrini, 1969). Alternatively, prophage duplications may arise by recombination among the duplicate genomes in a single cell subsequent to DNA replication. Both replication and recombination models suggest a tandem arrangement of the two $\lambda d g$. In support of this we have isolated a transductant clone with the genetic constitution gal $^{+}(\lambda d g, \lambda)$ from a P1 lysate made on a TMGr strain. Due to the DNA size limits of transduction by $P 1$, this transductant could be produced only if the $\lambda d g$ prophages in the donor strain were in tandem.

Gene duplication has been described as part of a mechanism by which a species may acquire new genes in an evolutionary process without concurrent loss of function in the original gene (Koch, 1972; Ohno, 1970). The duplication of part of the genome which takes place in $\mathrm{TMG}^{\mathrm{r}}$ lysogens may thus be another example of a prophage's ability to provide a selective advantage to the lysogen.

This work was supported by grant no. E524 from the American Cancer Society. The assistance of Joan Augustyn is gratefully acknowledged. The genetic studies presented were taken from a dissertation submitted by M. E. Raney to the State University of New York at Buffalo in partial fulfilment of the requirements for the Ph.D. degree. 


\section{REFERENCES}

ANDERSON, E. H. (1946). Growth requirements of virus-resistant mutants of Escherichia coli strain 'B'. Proceedings of the National Academy of Sciences of the United States of America 32, 120-128.

Brooks, K. (1965). Studies in the physiological genetics of some suppressor sensitive mutants of bacteriophage $\lambda$. Virology 26, 489-499.

Buttin, G. (1963a). Mécanismes régulateurs dans la biosynthèse des enzymes du métabolisme du galactose chez $E$. coli K-12. I. La biosynthèse induite de la galactokinase et l'induction simultanée de la séquence enzymatique. Journal of Molecular Biology 7, 164-182.

Buttin, G. (1963 b). Mécanismes régulateurs dans la biosynthèse des enzymes du métabolisme du galactose chez $E$. coli $\mathrm{K}-12$. II. Le déterminisme génétique de la regulation. Journal of Molecular Biology 7, 183-205.

ElliotT, R. W. (1970). Transductant clones in $E$. coli with altered regulation of galactose enzymes. Bacteriological Proceedings, 21-22.

GUERRINI, F. (1969). On the asymmetry of $\lambda$ integration sites. Journal of Molecular Biology 46, 523-542.

Kalckar, H. M., Kurahashi, K. \& Jordan, E. (1959). Hereditary defects in galactose metabolism in Escherichia coli mutants. I. Determination of enzyme activities. Proceedings of the National Academy of Sciences of the United States of America 45, 1776-1786.

KoCH, A. L. (1972). Enzyme evolution. I. The importance of untranslatable intermediates. Genetics 72, 297-316.

LeDERBERG, J. \& LeDERBERG, E. M. (1952). Replica plating and indirect selection of bacterial mutants. Journal of Bacteriology 63, 399-406.

LENNOX, E. S. (1955). Transduction of linked genetic characters of the host by bacteriophage P1. Virology 1, 190-206.
Morse, M. L., Lederberg, E. M. \& LederberG, J. (1956). Transductional heterogenotes in Escherichia coli. Genetics 41, 775-799.

OHNO, S. (1970). Evolution by Gene Duplication. New York: Springer-Verlag.

Olsen, I. \& Paigen, K. (1972). Polytransductant formation in Escherichia coli lysogens. Journal of General Microbiology 73, 113-126.

Packman, S. \& Sly, W. S. (1968). Constitutive $\lambda$ DNA replication by $\lambda c 17$, a regulatory mutant related to virulence. Journal of Molecular Biology 34, 778-789.

Rothman, J. L. (1965). Transduction studies on the relation between prophage and host chromosome. Journal of Molecular Biology 12, 892-912.

Russell, R. L., Abelson, J. N., LANDy, A., Gefter, M. L., Brenner, S. \& SMith, J. D. (1970). Duplicate genes for tyrosine transfer RNA in Escherichia coli. Journal of Molecular Biology 47, 1-13.

SHERMAN, J. R. (1963). Rapid enzyme assay technique utilizing radioactive substrate, ion exchange paper, and liquid scintillation counting. Analytical Biochemistry 5, 548-554.

Sly, W. S. \& RabideaU, K. (1969). Mechanism of $\lambda c 17 c I$ virulence. Journal of Molecular Biology 42, 385-400.

Swanstrom, M. \& Adams, M. H. (1951). Agar layer method for production of high titer phage stocks. Proceedings of the Society for Experimental Biology and Medicine 78, 372-375.

Weigle, J., Meselson, M. \& Paigen, K. (1959). Density alterations associated with transducing ability in the bacteriophage lambda. Journal of Molecular Biology 1, 379-386.

Williams, B. \& Paigen, K. (1969). Relationships between the regulation of the lactose and galactose operons of Escherichia coli. Journal of Bacteriology 97, 769-775. 